\title{
Afro-Hispanic Aesthetics and Identity through the Cuban Underground Hip Hop of Los Paisanos and Obsesión
}

\author{
Jessie D. Dixon-Montgomery • Knox College \\ "We are going to emancipate ourselves from mental slavery, \\ because whilst others might free the body, \\ none but ourselves can free our mind." \\ -Marcus Garvey 1937
}

\section{Reconceptualizing Identity and Culture through Hip Hop}

$\mathrm{T}$ The notion of aesthetics is a key aspect in shaping culture and determining one's identity and place within a culture. In all facets of the media, from popular ads to television and film, in literature and beyond, beauty plays a central role. In the new millennium, aesthetics become an increasingly more significant theme in underground hip hop as artists proudly promote an Afrocentric aesthetic. The songs, commonly known as temas, of Cuban underground hip-hop artists such as Los Paisanos and Obsesión $^{1}$ affirm their Afro-Hispanic identity through lyrics that examine the notion of beauty through an Afrocentric lens rather than one of the dominant Eurocentric culture, while examining critical issues of the day for Afro-Cubans. As Perry (2016) explains the significance of the term for rappers: "Given the centrality of social commentary and critique, raperos referred to their lyric-driven compositions as temas sociales or simply temas (social themes or themes) rather than the more prosaic canciones (songs)" (79). Through the underground hip-hop movement, they are able to effectuate self-affirmation, as posited by psychologist Claude Steele (1988), by focusing on positive aspects of their identity to maintain their self-integrity in the face of the marginalization and discrimination that threaten their collective identity and self-worth as African-descended Cubans. Steele explains that, "The goal of self-affirmation, as we have defined it, is to maintain an overall perception of self-adequacy. Thus, to restore this perception after it has been threatened, the adequacy that is affirmed must be able to offset, in importance to overall adequacy, the adequacy that has been threatened" (291)

Cuban underground or conscious hip-hop artists use rap as a means to advance black affirmation and social justice.
They were inspired by the hip-hop movement that originated in poor New York neighborhoods populated by AfricanAmericans and Puerto Ricans during the 70s. The musical genre reached its zenith from the mid 8os through the early 90s. Being revolutionary in nature, and like its predecessors in music and the visual arts, hip hop is more than a musical genre. It is a cultural movement that is made manifest through its multi-faceted cultural productions that include DJ's Breaks in the rhythms, breakdance, rapping MCs and graffiti (Hall 20). Indeed, in examining the pedagogical role of hip hop, Marcella Hall (2011) underlines that the vision of this movement is in line with the cultural productions. She points out the historical mission of pioneers such as KRS-One-commonly known as "The Teacher" — who affirm the transnational nature of hip hop:

Hiphop (Hip'Hop) is a term that describes our independent collective consciousness. Ever growing, it is commonly expressed through such elements as Breakin, Emceein, Graffiti Art, Deejayin, Beatboxin, Street Fashion, Street Language, Street Knowledge and Street Entrepreneurialism. Wherever and whenever these and future elements and expressions of Hiphop Kulture manifest; this Hiphop Declaration of Peace shall advise the use and interpretation of such elements, expressions and lifestyle. (Parker, 2003, p.8. cited by Hall 27)

These artists affirm and embrace their blackness, by focusing on their Black African hair, other black features and Afrocentric styles. In so doing, they bring to light the long history of socio-cultural ideologies that have stigmatized and erased blackness in Latin American culture. As Los Paisanos and Obsesión focus on black aesthetics in their underground hip hop, they compel their audiences to address the question of race, racism, and culture. Through their 
El negro cubano quiere ser igual que el blanco

porque cree que lo oscuro es atraso

y lo claro adelanto

tanto así que siempre está riéndose

de él mismo a carcajadas

cuando escucha algún chiste de racismo

...

El negro cubano se autodestruye a sí mimo

no se ayuda, se anula, se estrangula

en su egoísmo

es un tanto subdesarrollado

critica los drelocks

reverencia al pelo estirado

Negro, entiende asere

que el mundo es también tuyo

tu color y tu pasa son parte de tu raza

y tu raza y tu pasa tienen que ser tu orgullo

negro, tienen que ser tu orgullo

(Del Río. “El Negro Cubano”4)
The black Cuban wants to be equal to the white

because he believes that darkness is backwards

and lightness advances

So much so that he's always laughing

loudly at himself

when he hears any racist joke

$\ldots$

The black Cuban self-destructs

he doesn't help, he nullifies, he strangles

himself $\backslash$ in his selfishness

He is a bit underdeveloped

he criticizes the dreadlocks

he reveres straightened hair

Black man, understand homey

that the world is yours too

your nappy hair is part of your race

your race and your naps have to be your pride

black man, they have to be your pride

\section{Figure 1}

consciousness-raising lyrics, they exalt their "Afridentity" by identifying with and esteeming their African roots. In two of their most compelling songs, "Lo negro" and "Los pelos" ("Blackness" and "Hair"), the messages of these rap duos converge as they shift from an emphasis on skin color to hair texture to celebrate their African heritage. This analysis, however, proposes that "Lo negro" and "Los pelos" are consciousness-raising songs that go beyond affirming that black hair is beautiful. They insist that natural black hair texture and hairstyles are integral aspects of their aesthetics and identity as African-descended people. I argue that in doing so, they posit a rejection of the Eurocentric socio-political ideologies in Latin America that have deprecated blackness since slavery. Following the example of Black Americans in the United States who proudly affirmed their blackness during the late 1960 s and the 1970s, they present a discursive revolution that focuses on black hair texture as a way to dismantle the Eurocentric aesthetic that has played a key role in the perpetuation of racism, marginalization, and the oppression of African heritage people, and their Cuban compatriots in particular. The analysis and understanding of these songs empower their fellow African descendants to appropriately fight the mental and physical bondage that persists despite the legal end of slavery over a century ago.

Underground hip hop in Cuba facilitates the public forum for contemporary discussions of "Afridentity" among the young black and the population at large through highlighting the importance of hair texture in shaping the views of blackness and paralleling perceptions and treatment of blacks. Saunders (2015) asserts that through "Los Pelos" Obsesión challenges socio-cultural imposition as they point out the absurdity of having to alter one's natural hair texture to look more beautiful according to other standards of beauty (213). Hairstyling is a key aspect of enhancing one's beauty but the notion that a black woman can only be beautiful when her hair is altered to look European, or straight, is extremely unreasonable. Saunders notes that "[m]agia and Alexey link this standard of beauty to 400 years of "sleep" (colonialism). Obsesión argues that the culturally accepted aesthetic is also a colonial product. Through the song, Magia and Alexey speak to the corporal reality of blackness and the ways in which it is managed, dismissed, and devalued by those embracing racialized notions of beauty" (213). These artists' assertion of blackness is not limited to hair; it is multifaceted. However, placing hair at the forefront is a bold cultural and political statement after centuries of shaving, hiding, and altering hair to fit a Eurocentric aesthetic. Los Paisanos laud not only natural African hair but also skin color and other aspects of Afrocentricity. They proudly self-identify as black and they praise black artists and activists who fought on behalf of blacks for social justice. Perry (2016) notes the importance of Los Paisanos member Randy Acosta's affirmation of his black identity despite the cultural tendency to identify him as jabao (very light skinned with some European features): "Randy's comments suggest a shifting sense of racial identity in which hip hop is viewed as instrumental at both political and ontological levels of play" 
Sé que tengo mis facciones

un poquito extravagantes

muchos se ríen

porque se ven algo grandes

Pero, así nací

así soy y así me moriré

Con mi pasa dura te convenceré

Este es rap cubano

No lo confundas con benbé

Anda ven

Cógelo suave

Cógelo suave pa' que te dé

Negra

Negra con mi bemba

No hay quien me sostenga.

Negra con mi ñata y mi grande pata,

Así soy yo, negra

(Oye Habana. “Negra”)
I know that I have features

a little bit extravagant

many laugh

because they look somewhat big

But, I was born like this

This is how I am and this how I'll die

With my hard, kinky hair I'll convince you

This is Cuban rap

Don't confuse it with benbé [dance music]

Come on

Take it easy

Take it easy so I can give it to you.

Black woman

Black woman with my thick lips

There's no one who maintains me.

Black woman with my nose and my big leg,

This is how I am, black woman.

\section{Figure 2}

(Perry 61). Perry states that this mindset of black-affirmation led to their tema "Lo Negro," in which they examine "racialized stigmas that in their view inhibit black self-affirmation among Cubans of African descent" (61). Other rap groups such as Hermanos de Causa and the female trio Oye Habana also produced songs that highlight the natural, tightly coiled African hair as an essential feature in affirming blackness and celebrating the body, facial features, and color of African descendants.

In "Negro Cubano," by Soandry del Río, Hermanos de Causa address the tendency of some Afro-Cubans to despise and deny blackness as a result of cultural conditioning and ideologies that purported a national identity that transcends race in theory but privileges whiteness in practice. Soandry del Río points out that African ancestry, particularly evident in black skin color, hair texture, and Afrocentric hairstyles should be a source of pride rather than of shame and self-hatred. He asserts that Black Cubans foment their own erasure by perpetuating racist attitudes and practices inculcated by the dominant white culture. (see figure 1).

Soandry del Río posits that the Black Cuban has come to believe he is indeed inferior to the White Cuban and as a result seeks to disassociate himself from his race because in his society black is a signifier of backwardness, powerlessness, and ugliness. The focus on phenotypic markers such as color and hair are crucial in that they are tangible, highly visible traits seen in everyday life and have long been the target of racists assaults. As Saunders (2015) rightly puts it, "Soandry also addresses a key aspect of Black corporality: hair as a primary marker for blackness and the presence of stigmatized Africanness. He argues that the Black Cuban should embrace his body, embraces his race, embrace his hair" (130).
Similarly, the group Oye Habana, comprised of the artists Yordanska, Noiris, and Elizabeth, promote African aesthetics from the female point of view. In "Negra," they challenge Eurocentric standards of beauty that have regarded black women as unattractive and unworthy. They focus on physical features with pride and affirm their strength and the beauty and of their African, tightly-coiled hair, full lips, full nose and big legs. No longer will they accept the stigma of ugly assigned to them (see Figure 2).

Fernandes (2006) notes the importance of their stance in the context of a nation, supposedly free of racism, where blackness continues to be disdained, diminished and stigmatized:

Negative and racist descriptions of black-identified features are fairly common in Cuba; it is not unusual to hear complaints about pelo malo (bad hair) and mejorando la raza (improving the race) by having children with lighter-skinned people. The rappers of Oye Habana reject these stereotypes; they assert the beauty of African features and the power and presence of black women. (116)

In their music video, Oye Habana portrays a diverse group of females asserting and appreciating their black features. Notably, the cute little black girls walking, playing, and dancing joyfully are signifiers of the theme of black beauty. Their dark brown skin, their natural hair styled in Afro-puffs and ponytails puts them at the forefront as subjects that have the power to define themselves and their own aesthetics at an early age and set the standard for generations to come. The attire of the women 
rappers-dressed in black and military fatigues, with two of them wearing hats-are further signifiers of beauty of their strength. They project a revolutionary stance of proclaiming in Cuba through strong, dark-skinned women. Fernandes asserts that, "Cuban women rappers also use style to project a political message, and assert their individuality, presence, and identity as black women. Magia and the rappers of Las Krudas usually wear head wraps, African clothing or baggy shirts and pants, and natural hairstyles" (116). Oye Habana defies the national image projected by the Federation of Cuban Women (Federación de Mujeres Cubanas) of the Cuban woman as a light-skinned, straight haired woman, dressed in fatigues while carrying a baby and a gun (Saunders 200). Black women of all ages, sizes with hues and natural hair celebrate their black features as these rappers' sing tribute to the Black woman.

The focus on black self-identification and African aesthetics in underground hip hop is essential in addressing the dominant Eurocentric culture in Cuba. The role of the rappers is two-fold; they are artists and activists. These "artivists" seek to awaken the consciousness of Cubans with regard to race and to combat the real, lived experiences of racism and social injustice (Saunders 9). Thus, underground hip hop is more than a musical genre; it is a movement:

[W] hat you do with your body and what cultural traditions you publicly embrace indicates your social racial classification and your racial self-definition. Aesthetics are political in such a way that "form" functions as a political discourse. The racialization of culture and the imposition of Eurocentric aesthetics as the cultural and corporal ideal are central to cultural practices in Latin America and the Caribbean; they are also central to identity formation throughout the hemisphere. While race is largely defined by blood in the United States, it is primarily defined by phenotype in Latin America and the Spanish-speaking Caribbean. (Saunders 46)

Through their lyrics and their style, these artivists compel their audience to reexamine blackness as they revisit and reevaluate the notions of Cuban identity that have been posited over the centuries. During the late 19th century, Cuban liberator José Martí (1893) promoted the unity of all Cubans in his speech "Mi Raza" (My Race): “Todo lo que divide a los hombres, todo lo que los especifica, aparta, acorrala, es un pecado contra la humanidad (Everything that divides man, everything that specifies, separates, or traps them is a sin against humanity." He went on to say that, "En Cuba no hay temor alguno a la guerra de razas. Hombre es más que blanco, más que mulato, más que negro. Cuba es más que blanco, más que mulato, más que negro." (In Cuba, there is no fear of a race war. Man is more than white, more than mulatto, more than black. Cuba is more than white, more than mulatto, more than black) (Lazo 52). Considering that the emancipation of blacks took place in 1888, after nearly four centuries of slavery on the island, the fight for Cuban independence, and the slaughter of thousands of blacks and the Independent Party of Color (Partido Independiente de Color or PIC) in the Massacre of 1912, it stands to reason that the perception of blacks as inferior still persisted in the developing Cuban nation at that time. Nearly five decades later, in his major work Cuban Counterpoint of Tobacco and Sugar (1940), renowned Cuban anthropologist and ethnomusicologist Fernando Ortiz echoed the sentiment that Cubans are not merely black or white. He posited that Cubans are a complex mixture of cultures that have blended and transformed over time to become what is now Cuban culture. He coined the term, transculturación, "to express the highly varied phenomena that have come about in Cuba as a result of the extremely complex transmutations of culture that have taken place [on the island]" (Ortiz 98). Ortiz affirmed that the intersections and transmutations of the various cultures in Cuba have resulted in the creation of a new culture that incorporates and appreciates all of its roots-Indigenous, Spanish, African, and later Asian. To further elucidate this idea, Ortiz used the metaphor of the ajiaco-the national stew prepared with multi-heritage ingredients-to describe Cubanidad or cubanía, that is, the essence of what it means to be Cuban. Nonetheless, the racial tensions and inequality that prevailed throughout the Revolution of 1959 and the new millennium, evince that while all cultural ingredients may be appreciated in the ajiaco, not all are valued equally by the Cuban people. Perry asserts that Ortiz's concept of Cubans as a transcultured people is more aptly put as racially neutralized (82). Cuba promotes a national identity that celebrates the mestizo but sacrifices African descendants in so doing. As in other countries whose populations include African descendants, the binaries of white/black and superior/inferior do persist, resulting in a caste system of pigmentocracy in which black people, dark-skinned mulattoes and mestizos are disenfranchised and marginalized. Through "Lo negro" and "Los pelos," we are urged to reexamine the notion of transculturation in Cuba through the contemporary lense of hip hop rappers. The rappers promote their blackness and in so doing demystify the propaganda of a multi-heritage Cuba that embraces equally all of its cultural roots.

\section{Affirmation of Blackness in "Lo negro"}

As mentioned earlier, Cuban rappers like Los Paisanos and Obsesión, have used hip hop to address the socio-cultural and racial situation in Cuba while affirming blackness. This is also true for a number of their contemporaries such as Anónimo Consejo, Ticuna and Las Krudas. Fernandes (2003), in her analysis of Cuban underground hip hop, discusses the focus of Cuban rappers as follows: "Attracted by the Black nationalistic practices of certain African American rappers 
Mi misión no es criticar

Ni hablar mal de las personas

Sólo ver cómo razonan

Sólo ver cómo funcionan mis palabras

Liberarte del dolor

Como el doctor Álvarez Cambras

(Los Paisanos. “Lo negro”)

\author{
My mission is not to criticize \\ nor speak badly of people \\ Just see how they reason \\ Just see how my words work \\ Free you of pain \\ like Dr. Alvarez Cambras
}

\section{Figure 3}

who have coined the term "underground" or "conscious" rap, Cuban rappers offer criticism of neoliberal globalization as they propose the notion of Cuba as a Black nation struggling for justice in an inegalitarian world order" (57).

In their album Paisanología (2003), Los Paisanos, formed by the duo Randy Acosta and Mr. Huevo (Jessel Saladriga), promote black identity and reflect upon the daily struggles of the Cuban black masses through their underground hip hop, which they see as a means of consciousness-raising and resistance in a nation where white skin privilege still exists in spite of the official policy and the initial advancements of the Revolution of 1959. The song "Lo negro" seeks to awaken the people as it motivates them to take an introspective look at blackness within the Cuban context. Perry notes that initially their connection with African Americans inspired their ideas and action to assert positive perceptions of blackness: "In the case of early raperos, plays upon black-identified U.S. music and style forms may also be seen as efforts to negotiate new grammars of Afro-Cuban-ness as a means of marking racial difference while expanding the terms of Cuban blackness itself" (Perry 77). Through focusing on the natural hair of African descendants, they seek to inculcate pride in one aspect of the collective black identity and break the chains of a cultural aesthetic that threatens black people's self-image. In so doing, they affirm their blackness and empower themselves psychologically for resistance against the racist ideologies that perpetuate the oppression and stigmatization of African-descended Cubans (see Figure 3).

Although its songs are provocative, underground hip hop does not intend to undermine the Revolution or overthrow the government but rather to cast light on the current problems that neither of these has been able to eradicate.

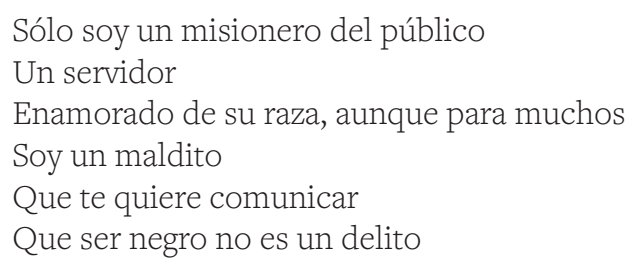

Moreover, it represents the voice of the underdog, those who suffer marginalization and disparagement due to persistent racism that the political discourse from the end of the 19th century to the present does not acknowledge. Although Martí claimed that "[e]n Cuba no habrá nunca guerra de razas (in Cuba there will never be a race war) because "La afinidad de los caracteres es más poderosa entre los hombres que la afinidad de color" (the affinity of characteristics is more powerful among men than the affinity of color), not only do racism and racial inequality still exist, but they resurged boldly after the collapse of the Soviet Union and the resulting Cuban economic crisis during the Special Period (Lazo 53). Roberto Zurbano (2015) affirms that after the Revolution of 1959 conditions improved for the majority of blacks and mestizos, who had been marginalized in terms of poverty, health, education, and racism, however, he notes how progress reverted towards the end of the twentieth century: "El rechazo a cualquier tipo de discriminación se incorpora como parte del ejercicio revolucionario cotidiano. Era impensable, pues, que la discriminación racial, definida y combatida como un rezago burgués, pudiera regresar con la fuerza e impunidad con que se reinstala en la isla durante los años noventa del siglo XX" (Zurbano 16). Faced with a resurgence of racism and poverty, young Cuban rappers saw hip hop as a way of making a political statement about their blackness and the lack of equality in Cuba (Fernandes 89). Los Paisanos assert that raising people's consciousness through their verses is crucial, since keeping quiet and ignoring reality has harmed the people and the government's ability to work for the good of all of its citizens (see Figure 4).

It is fair to say that the concerns and outcry of the duo and of the masses have not been ignored by the government

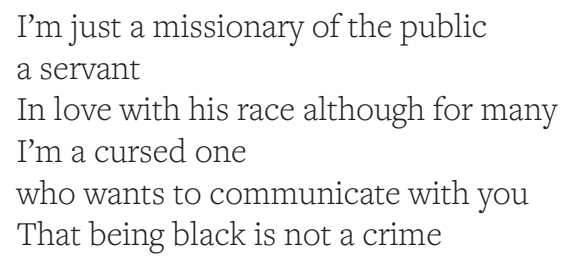

\section{Figure 4}




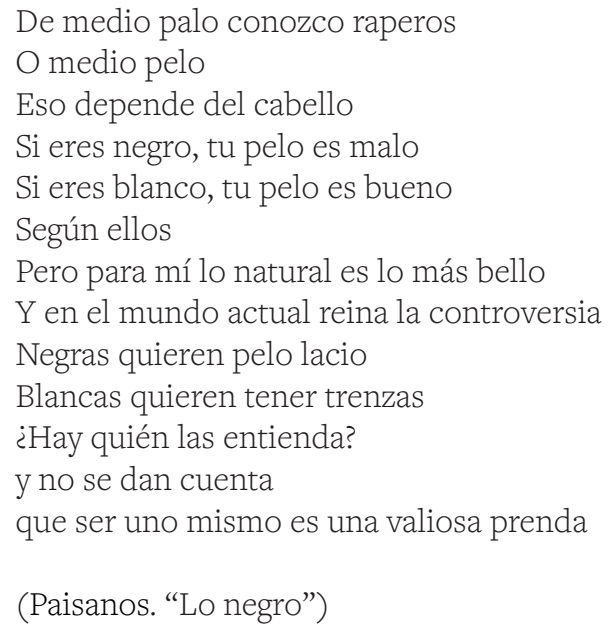

\section{Figure 5}

in recent years. In 2013, in a report on racial problems in Cuba, the Parliament decided to take this issue seriously when it publicly admitted that racism still exists, and that it supported sincere efforts to combat racism. ${ }^{2}$ As previously stated, although much was accomplished during the first years of the Revolution with regard to institutional racism and poverty, inequality and racism still exist. De la Fuente (2008) notes the recent discussions of artists and scholars on the silence regarding the issues of race and racism in Cuba. Moreover, he rightly points out that they still persist despite the efforts of the Revolution of 1959 that has sparked more “contradictory explanations" (De la Fuente 697-98). Proclaiming an end to racism with the change of government was simply idealistic in a society whereby the institution of slavery had established and fomented inequality and prejudice based on race for centuries. Moreover, not addressing the resulting mindset of such ideologies contributed to the sustained existence of racism. Zurbano asserts that the behavior of Cuba's socialist policies were counterproductive to combating racism: "su propia ceguera ideológica ante la supervivencia y renovación del racismo, después provocando un largo silencio sobre el tema y, finalmente, no asumiendo, explícita o implícitamente, alguna política racial o estrategias, directas o indirectas, con qué enfrentar la presencia del racismo en la isla" (Zurbano 17). Los Paisanos break the silence and seek to uncover the racial issues that continue to affect people in various aspects of their lives.

In "Lo negro," Los Paisanos speak boldly about one important aspect of identity that resonates in the psyche of black people, the question of aesthetics, that is to say, the notion of beauty and its impact on the mindset of black women and men. Since the colonial era in the Americas, we have seen a tendency to favor not only white skin, but also European facial features and hair as the epitome of beauty. During slavery, nomenclature about the physical aspects of black people emerged in Cuba, as in other

\author{
I know half-baked rappers \\ or second-rate \\ That depends on the hair \\ If you're black, your hair is bad \\ If you're white, your hair is good \\ According to them \\ But for me natural is the most beautiful \\ And in the current world the controversy reigns \\ Black women want straight hair \\ White women want to get braids \\ Is there anyone who understands them? \\ And they don't realize \\ that being oneself is a valuable garment.
}

Hispano-Caribbean countries. Derogatory terms such as, "la pasa," "el hocico" and "la bemba" (nappy hair, snout and bubble-lips) are commonly used to denote natural, tightly coiled hair, wide nose and thick lips of African heritage people. Women, and to a lesser extent, men, continue to be criticized for their kinky hair. Throughout childhood and into adulthood the black woman often experiences insults and mistreatment as her hair is combed or the texture is altered. Her "crown of beauty" becomes a crown of thorns. Jorge analyzes this hair dilemma in her study on the Afro-Puerto Rican woman. As a small child, a girl with curly hair, specifically the coiled hair associated with people of African descent, tends to hear comments that inculcate that notion of ugliness equated with her natural hair: "Maldito sea este pelo," "Péinate la pasa," "Pelo caracolillo," "pelo malo" ("Damn this hair," "Comb those naps," "Nappy hair," "bad hair”) (184). United States filmmaker Spike Lee presented the same theme in his film School Dayz (1988) in the musical scene "Nappy Hair," in which the girls with natural kinky hair debate with those who have straighter hair-whether it's naturally so or chemically altered. Without a doubt, it is a reality that affects many women of African heritage, especially those whose phenotype is clearly black. The images that surround her in the beauty advertisements and in the media present straight, long, and typically blond hair as the ideal beauty. Los Paisanos denounce the ubiquitous nature of this problem in Cuba as follows: "Tanto en la calle como en la casa. La pena, vivir esta farsa" (Paisanos. "Lo negro”). This is why it should come as no surprise that for decades black women, more than others, have taken great pains to style their hair and make it look more European. Los Paisanos comment on this racial dichotomy at the very beginning of their song (see figure 5).

Drenched in language and imagery that reflect an underlying negative linkage between racial identity and hair texture, along with the contrast between natural hair styles 
Con sí mismo se comenta que el racismo

empieza con nosotros mismos

Te dicen que eres negro

Tú dices que eres mestizo

Enfatizo los típicos desertores de la raza

Se casan con un blanco

Pues no quieren peinar pasa iTRAGEDIA!

Tanto en la calle como en la casa

La pena, vivir esta farsa

(Paisanos. "Lo negro")
With oneself one comments that racism

begins with us

They tell you that you're black

You say that you are mixed

I'm emphasizing the typical deserters of the race

They marry a white man

'Cause they don't want to comb naps. TRAGEDY!

In the streets just like at home

The sorrow, living this farce

\section{Figure 6}

and the fleeting affinity for fashion, their verses show the dilemma of black men and women as they experience alterity in a post-revolutionary, supposedly post-racial society. The language used in describing physical traits of black people is a reflection of the Eurocentric ideologies that have played an injurious role in creating complexes and self-esteem issues among black people. Indeed, the connotations associated with hair reveal the manifestation of prejudice against black people-de medio palo (incomplete, half-baked) and de medio pelo (second-rate), and they suggest the tendency of some rappers to not be "conscientious" 3 in their artistic production. Likewise, this suggests the problems that they share with their fans, who for the most part are young blacks who endure the negative images associated with blacks. Black African, tightly-coiled hair is another hair type. It is merely different from other hair textures. However, it has been assigned an aesthetic value-a negative one that goes beyond the surface. That is, it infers that not only is the hair bad, but is also a signifier that the individual who has that hair type is bad. In his psychoanalytic study of blackness in Black Skin, White Masks (1967), Martinican psychiatrist Frantz Fanon affirms that this phenomenon is the origin of Negrophobia in the Antilles. "In the collective unconscious, black = ugliness, sin, darkness, immorality. In other words, whoever is black is immoral" (Fanon 192). Los Paisanos highlight the problem of living in a society where the affinity for European features results in a low esteem of oneself and in the negation of the natural beauty of blacks. They also suggest that, ironically, when white women wear hairdos that are "traditionally worn by blacks," that simply reflects a fashion trend, not a deprecation or rejection of themselves. Thus, while for white women, the decision to wear these hairstyles is not associated with natural hair stigma, such is not the case with black women. What is projected externally by mainstream Eurocentric culture and unfortunately assimilated by blacks has been ingrained in the psyche of black people for ages.

Underground hip hop works to counteract the Eurocentric mindset. It goes without saying that the impact of hip hop on fashion is evident worldwide. The fans, irrespective of their skin color, wear baggy pants and flashy jewelry (bling-bling); men as well as women, whether black, white, or brown, wear braids and dreadlocks. Saunders (2015) notes the cultural significance of rappers wearing dreadlocks in Cuba: "The dreadlocks are important in the context of a country that encourages people with tightly curled hair to straighten or shave their hair. People who not only refuse to do so but also grow dreadlocks are rejecting the hegemony of European aesthetics in Cuban culture and embracing their blackness" (29). Cuban women rappers also wear natural hair and Afrocentric hairstyles and African clothing or baggy clothes to reflect their conscious "Afridentity" (Fernandes 116). Nonetheless, the vast majority of images of feminine beauty in Cuba still portray a European aesthetic. This is what positions hair to be at the forefront of the struggle to liberate oneself from mental bondage, as the legendary Jamaican Pan-Africanist Marcus Garvey (1937) urged nearly a century ago.

As I have pointed out, "Lo negro" begins with the hair as the focal point but with each verse and stanza the rappers delve deeper into their discussion of the racism that keeps people mentally enslaved. They direct their discourse to the blacks and mulattoes who seek to diminish or deny their black heritage and endorse the ideology of whitening commonly promoted in Latin America and the Caribbean. That is, they opt to "advance the race" by marrying whites so that their children will be whiter and thus have more opportunity to improve their status in society (see figure 6).

It is important to note that the discourse of whitening dates back to 1776 with the royal decree from King Carlos IV of Spain, el Gracias al Sacar (Thanks for the Exclusion). This law permitted mulattoes to change their race, or caste, legally to the white race so that they could improve their socioeconomic status. Piedra (1987) examines whitening in the context of literary whiteness after the Age of Enlightenment as part of the Imperial Spain's efforts to foment a common, homogeneous language as key to establishing a unified empire. He notes several cases in which an individual's race was changed legally in order to facilitate access to opportunities that were limited to whites. Piedra highlights the most notable case of Pedro Antoni 
NEGRO Es mi pensamiento

NEGRO Son mis movimientos

NEGRO Es como me siento

NEGRO Por fuera y por dentro

NEGRO Fue Jesús Menéndez

NEGRO Bob Marley con su prende

NEGRO Color que no se vende

NEGRO iPuño arriba si me entiendes!

(Paisanos. "Lo negro”)
BLACK is my thought

BLACK are my movements

BLACK is how I feel

BLACK inside and outside

BLACK was Jesús Menéndez

BLACK Bob Marley with his take

BLACK color that is not sold

BLACK Fist up if you understand me

Figure 7

de Ayarza, a pardo captain from Colombia, who petitioned for a change in racial status for his son so that he could earn a law degree in 1797 . He was granted whiteness through the Gracias al Sacar, through which "[t]he King's written permit circumvents racial differences in favor of an act of rhetorical blindness, whereby the "character of mulatto [a less desireable term than pardo] being held extinguished in him, he be admitted, without its serving as a precedent to the degrees he may seek in the university ...."” (Piedra 321). Likewise, Watson (2010) notes that whitening has been embraced throughout Latin America, where notions of race and nationality have been intentionally coalesced and "have excluded people of color by reinforcing national discourses of homogeneity" (171). Watson asserts that despite the nationalist rhetoric, Panamanian nationalist poet Federico Escobar (1861-1912), goes against the grain and "utilizes the opposition between lightness and darkness to elevate blackness and deviates from the cult of whiteness" (177).

The masterfully-crafted lyrics of Los Paisanos reveal that centuries after the abolition of slavery in Cuba in 1886, and even decades after the 1959 Revolution, those notions of white superiority and the associated privileges in contrast with the presumed inferiority of blacks still persist. Los Paisanos embrace blackness as they challenge other blacks to reject the discourse and practice of whitening. In pointing out the role of black people in accepting these notions and perpetuating them, Los Paisanos assure us that not only do people of African descent have the power to change these racists beliefs, but they also have an obligation to do so. Their verses are reminiscent of the same sentiments expressed in "Redemption Song" by Bob Marley in the 1980s as he exhorted black people to, "Emancipate yourselves from mental slavery. None but ourselves can free our minds" (Marley “Redemption Song”). Marley's statement echoes that of Marcus Garvey's speech in the first decades of the twentieth century. Marcus Garvey asserted in his 1937 speech:
We are going to emancipate ourselves from mental slavery because whilst others might free the body, none but ourselves can free the mind. Mind is your only ruler, sovereign. The man who is not able to develop and use his mind is bound to be the slave of the other man who uses his mind, ... (Garvey 791)

In his song, Marley re-affirms what Marcus Garvey posited in his speech-that we alone have the power to liberate our mind. Los Paisanos question those who continue to perpetuate racist ideologies while proclaiming at the same time their blackness, their negritude: "I was born black as I am / And what I am does not embarrass me." Furthermore, they affirm that the true "beauty of people is right here in their heart" (Paisanos. "Lo negro"). This is not a cliché. It is undoubtedly at the core of their affirmation of blackness. The focus on one visible trait, the hair, and recognizing its beauty is a self-affirmation that has the power of penetrating one's psyche and manifesting itself externally. Valuing oneself is the advice that Los Paisanos give to their compatriots in order to fight against racism wherever it might be lurking so as to achieve the collective liberation of the Cuban people.

Through their conscious hip hop, they bring to light the persisting attitudes and behaviors that privilege white Cubans while marginalizing the black ones. They exhort all Cubans to be active participants in the revolution against racism, which not only oppresses blacks but also threatens the liberty and prosperity of all Cubans. In "Lo negro," Los Paisanos sing of blackness with pride and insist on the importance of being faithful to oneself. They laud African-descended natural hair through an Afrocentric aesthetic to self-affirm the collective identity of black people (see Figure 7).

\section{From Self-affirmation to Reconceptualization of Black Beauty in "Los pelos"}

Continuing the discourse on the intersection between aesthetics and racism, Magia López and Alexey Rodríguez, 
Pelo suelto carretera

No hay derriz

Me di cuenta que pa' qué

si yo no nací así

El hombre que me quiera

Me acepta como soy

AFRICANA

Adondequiera que voy

(My translation with the help of Sergio Daquin)
Loose windblown hair

There's no relaxer

I realized for what

if I wasn't born like that

The man who loves me

Accepts me as I am

AFRICANA

Wherever I go.

\section{Figure 8}

of the duo Obsesión, recognize the importance of self-affirmation through emphasis on Afrocentric aesthetics that Los Paisanos posit in their music. They advance the discourse on black aesthetics and esteem by dedicating a theme to the hair, the beauty of natural, African-heritage hair. Saunders asserts the crucial role of Magia as "the first woman MC to emerge with an explicitly Afrocentric discourse and identification within the Cuban Underground Hip Hop Movement" (Saunders 205). As her eyes were opened to black consciousness, she embraced her black identity and became empowered. Through hip hop, Magia and Alexey sought to share that awareness with other Afro-Cubans. They form part of the transnational conversations that promote Afrocentricity and speak out against racism. In his analysis of the Afro-Cuban culture movement, de la Fuente insists that racism has not been eliminated, and that after the fall of the Soviet Union in 1991, the youth of the hip-hop generation saw an erosion of the egalitarian state and a "resurgence of racism and discrimination in Cuban society" (699). I would like to examine at this juncture the effects of racial prejudice in the context of aesthetics and the millennial re-conceptualization of beauty in the underground hip hop of the duo Obesión. As stated earlier, one of their most notable songs highlights the outstanding phenotypical trait that has been altered, despised and rejected over the centuries: natural, coiled hair. In Latin America, where phenotype is the major indicator of racial identification, hair is often the indicator of African ancestry when light or white skin and European features would otherwise result in classification as white. In a social context where the Eurocentric aesthetic and culture are dominant, natural African hair is a signifier of unattractiveness and powerlessness. Given the societal norms that impose and promote a Eurocentric standard of beauty, awakening black consciousness and embracing an Afrocentric standard is crucial for the collective self-affirmation of black people. Evocative of the African-American slogan of the 1960s "Black is Beautiful!" and of the pride in Blackness evinced in the artistic production of the African Diaspora, "Los pelos" (Hair) brings to the forefront the struggle to have African heritage recognized and valued as much as Hispanic heritage while also celebrating their cubanía.

Through this hip hop ode to hair, it becomes even clearer that hair, just like skin color, is an essential part of black identity and self-esteem. All of the aspects of the phenotype that determine physical appearance-color, facial features and hair texture-are linked to the identity and alterity of an individual. These aspects of the phenotype are considered to identify, value and compare individuals with members of their racial or ethnic group, and to contrast them with those other groups. In societies where there is cultural diversity or specifically racial diversity intricately woven with a long history of domination and oppression, valuing one phenotype over others has left a long-lasting impression of internalized racism on the psyche of the people and has resulted in the marginalization of those who do not belong to the privileged phenotype. Thus, the significance of hair in the context of black communities within Eurocentric dominant cultures goes much deeper. Hair is not simply a grooming issue that all women deal with equally. Hair represents beauty but it is linked to a racial identity that is judged acceptable or not and thus, is either awarded or denied privilege. Banks (2000) notes in her study Hair Matters that "within a broader context, they [non-black women] do not have to deal with cultural and political constructions of hair that intersect with race and gender in relationship to mainstream notions of beauty, putting a great number of black women outside of what is considered beautiful in U.S society. For black women, hair embodies one's identity, beauty, power, and consciousness (38). In Cuba, as in other nations of the Spanish-speaking Caribbean and the Americas, black women face the same dilemma given the longstanding tradition of promoting the white, European phenotype as the ideal of beauty. Confronted with those ideologies, Obsesion responds boldly through "Los pelos" to affirm black beauty and blackness, to reeducate and to encourage black people to boost their self-esteem. In so doing, they are empowered to dismantle the European aesthetic of beauty that is linked 
Mi naturaleza rompe patrón de belleza

No me vengan con que pa' lucirme fina...

Hay que plancharse la cabeza

para verse más femenina

iÓyeme no nananina!

Mis códigos determinan

Yéndose por encima de todos esos esquemas

se encaracola mi pelo

y es postura ante la vida

(Obsesión. "Los Pelos")
My nature breaks the model of beauty

Don't come at me with that in order to look fine...

You have to press your hair

to look more feminine

Hey don't gimme that (nananina)!

My codes determine

Going on top of all those schemes

my hair coils

and is a stance facing life.

\section{Figure 9}

to the perpetuation of racism in Cuba. As Saunders asserts, this theme "speaks directly to Black identity politics" (213). Indeed, challenging societal norms by embracing natural African hair is self-affirming and liberating.

The video of "Los pelos" (2011) presents the image of beauty from the introspective viewpoint of a black female rapper, Magia López, and her husband Alexey Rodriguezwho sings in the background supporting and appreciating her in all of her splendor. Together they demonstrate and profess the beauty of tightly coiled African hair in its natural state. Magia, who is the centerpiece of the song, is the author and subject of her own text on identity and the aesthetic value of an Afro-Cuban woman. Through her rap, she defies the images of beauty that have exalted the white woman and mulata but excluded her. She boldly confronts the ideologies of a society that privileges Whitenesswhite skin, facial features, and hair that are characteristic of European ancestry. Their lyrics contest the images and the ideologies that scorn African features while idealizing Caucasian traits, and by extension the whitened features of mulatas (see figure 8).

Listening to the lyrics evokes two impactful yet contrasting images in the collective memory of African Diaspora people: "straight, windblown or 'highway hair"” and natural coiled hair without a relaxer. As mentioned earlier, for years, the portrayal of feminine sensuality through loose, flowing hair has been projected in all of the cultural productions of Western society - in art, literature, popular magazines, television, and theatre. These images are not of tightly coiled or kinky African hair, but of straight, long European hair that is gently caressed and disheveled by the wind. For women of African heritage, this image can provoke a manifold of sentiments. On one hand, it inspires the desire to look sensual and attractive like the women represented, but on the other hand it inculcates self-deprecation for those with non-European hair. The latter group consequently yearns for straight hair and even becomes obsessed with altering their hair to look fine and straight, that is, more European. Rooks (1996) notes this hair dilemma through nineteenth-century advertising in the U.S. that promoted products aimed at altering black women's hair to mimic a European model of beauty:

[T] he merchandising, by white-owned companies, of hair-care products specifically designed to straighten hair have appeared in African American periodicals, However, just as the products could only promise a caricature of white standards of beauty, so too the pictures that accompanied the ads were caricatures of a standard of beauty that was difficult, if not impossible, for African American women to meet. (13)

Kutzinski (1993) notes the tendency to degrade blackness while privileging whiteness in Cuban cigar and cigarette advertisements from the nineteenth century in which caricatures of black women are often defeminized and asexualized in juxtaposition with the mulata, who is sexually objectified (64). Despite this long-standing mindset of idealizing whiteness and deprecating blackness, López boldly sings her song and displays her natural, coiled hair and other African features in her accompanying video. López extols her hair as she parades through the Cuban streets with her reddish-brown unrelaxed hair let down, proudly showing her beauty that is inextricably linked to her African heritage. For the woman with natural coiled African hair, this is an act of resistance and self-affirmation that defies the national discourse that acclaims the light-skinned mulata as the face of Cuba and the symbol of transculturation. Again, by wearing her natural hair "suelto carretera," López defies the national image of beauty and the notion that natural African hair is not beautiful or sensual, and that women of African descent are inferior. Her natural hair reflects how natural hairstyles in the new millennium have taken on the role of the Afro of the 1960s, which became fashionable but more importantly "was understood to denote black pride, which became synonymous with activism and political consciousness" (Rooks 6).

This conscious decision to not conform to the norms that dictate a European aesthetic of beauty-a legacy of slavery in 
Una doctrina que consolida

Esta imagen que te vengo dando

Conmigo duermen más de 400 años

Soñando con el, ¿Hasta cuándo?

El procedimiento te estira el pelo.

Lo hace mentiroso

Opacando lo que naturalmente es hermoso.

(Obsesión. "Los Pelos”)

\author{
A doctrine that consolidates \\ This image that I'm coming to you with \\ More than 400 years sleep with me. \\ Dreaming about, Till when? \\ The process straightens your hair. \\ It makes it a liar. \\ Overshadowing what is naturally beautiful.
}

\section{Figure 10}

the Americas - presents a dilemma for the black woman. For centuries, Western society has imbibed the culture with the notion that "good hair" is straight and long, or long and wavy. But coiled or kinky natural African hair has not been lauded as "good hair". As previously noted, these ideals of beauty have been disseminated orally, in written texts and through images projected in all forms of media and advertisement. Thus, the women and men who do not conform or adapt to this Eurocentric standard of beauty tend to endure marginalization and ostracism from whites, mestizos, mulattoes and others who conform to the white aesthetic. Faced with these oppressive ideologies, López experiences an awakening. She reveals that she realized - she has truly realized-that she wasn't born with straight hair. Her natural African hair is now a signifier of beauty and power as she defines what Black identity means. Her bold Afrocentric stance and style had a powerful impact on Afro-Cuban women who saw her performing hip hop (Saunders 215).

Her appreciation for her natural hair liberates her from an aesthetic that is not appropriate for her and frees her from the perpetual struggle to alter her hair by straightening and relaxing it so that it looks more European. As stated earlier, this is an act of physical and mental resistance. Through the radical act of wearing her hair without relaxing it, she becomes empowered to esteem herself according to an Afrocentric standard of beauty, which is perfectly in line with her hair and her other physical features. She realizes that if others were able to create and impose their standard of beauty, she also has the power to reject it and create her own (see Figure 9).

It is essential that she define her beauty in order to be an active agent of determining her self-esteem and worth in society. In doing so, she is able to reclaim the beauty of generations of women who have been ridiculed because of their kinky, coiled hair, not to mention their objectification as the 'Mammy' or 'bad Black woman' (Collins 70). Obesión's ode-manifesto to the hair functions as a way to disseminate a re-conceptualization of the image of the black woman that goes beyond the surface. Her appreciation for her external beauty is a reflection of the underlying sentiments in her psyche. Not only does she accept her hair, she also esteems it. Thus, by extension she is able to reclaim her integrity and love herself just as she is, and wholly so. Her pride in herself uplifts and reassures other women who share her African roots.

Obviously, not only women share this "idiosincrasia capilar" (hair idiosyncrasy). Black men also endure it but given the importance it has taken in our society with regard to feminine beauty, it is necessary to focus more on women. The affirmation from her husband is an important indication that he understands her plight. He knows how significant his support is concerning her self-esteem. Their mutual appreciation of the aesthetic value of their natural African hair reinforces in both of them the confidence and their belief that black is beautiful. They therefore have the legitimate right to proudly wear it "au naturel" (see Figure 10).

\author{
Yo te enseñooooooooo \\ ¡Pa' arriba los pelos \\ y qué crezcan los grelos! \\ Yo te enseñooooooooo \\ Al que le guste bien \\ $\mathrm{Y}$ al que no también
}

(Obsesión. "Los Pelos”)

\author{
I'll shoooooooow you. \\ Up with the hair \\ and let the dreadlocks grow. \\ I'll shoooooooow you. \\ To him who likes it, good \\ and to him who doesn't too.
}

\section{Figure 11}


Identidad siempre dispuesta

Orgullo sale a la palestra

iMira! Obsesión dice y demuestra

Convicción en talla extra

Dime entonces si tú sales o entras

O lo escondes o lo muestras

$O$ te pierdes o te encuentras

Tú piénsalo que yo mientras

Voy a seguir en la pelea de

A partir de lo que somos

Entonces lo que sea.

(Obsesión. "Los Pelos”)
Identity always ready

Pride goes out to the arena

Look! Obsesión says and shows

Conviction in extra-large

Tell me then if you're leaving or coming

Either you hide it or you show it.

Either you lose yourself or you find yourself.

You think about it and meanwhile I

I am going to continue the fight for

Starting with what we are

Then whatever.

\section{Figure 12}

Through "Los Pelos", Obsesión reasserts conscious hip hop as an act of resistance that confronts centuries of cultural impositions that have psychologically enslaved black people. In praising black hair, this rap duo defies the ideology of "mejorar la raza" (improve the race) that characterized Latin-American identity politics. This ideology perpetuates the rejection and the intentional eradication of part of the heritage of the Latin America and the Spanishspeaking Caribbean, the black heritage (Whitten and Torres 75). This unwritten yet understood ideology purports to "advance" and improve the race by marriage and procreation with whites in order to have children that are progressively less black, and consequently whiter and with straighter hair in subsequent generations. In a society that privileges whiteness, this whitening is a socio-economic strategy that attempts to enable offspring to have opportunities to advance their status in society. However, this mindset of "adelantar la raza" perpetuates the dichotomy between white and black, which unfortunately is likened to the dichotomy between good and bad. Obsesión rejects those ideologies as they posit black self-affirmation (see figure 11).

Through the refrain that stands out boldly, they proclaim their "Afridentity" by uplifting black people who wear their natural hair and embrace blackness. It is not simply an inversion of the status quo of the white aesthetic. It is a reconceptualization of the beauty and, by extension, the worthiness of blacks. As Frantz Fanon rightly asserted decades ago, one has to transcend the ideologies that harm the psyche and create one's own norm. From that point on, one can be proud:

In order to terminate this neurotic situation, in which I am compelled to choose an unhealthy, conflictual solution, fed on fantasies, hostile, inhuman in short, I have only one solution: to rise above this absurd drama that others have staged round me, to reject the two terms that are equally unacceptable, and through one human being, to reach out for the universal. (Fanon 197)

Indeed, Obsesión rejects the cultural practices that inculcate a notion that black is inferior and re-conceptualizes beauty and self-esteem on their own terms. They uphold blackness wholeheartedly for themselves and encourage their compatriots to do the same. Following Fanon's advice, they refute the dominant culture's ideologies that purport the inferiority of and disdain for blackness. Instead, they assert and define themselves and their beauty through an Afrocentric aesthetic (see figure 12).

This analysis of "Lo negro" and "Los pelos" demonstrates how Los Paisanos and Obsesión reconceptualize AfroHispanic aesthetics and identity through underground hip hop. With hair as the focal point, they are able to promote and protect the integrity of a collective black identity by extoling the beauty of natural Black African hair. I argue that this self-affirmation, by extension, advances the discourse and empowers African-descended people "to emancipate ourselves from mental slavery" of ideologies that deprecate blackness and to define and embrace blackness through an Afrocentric frame of reference (Garvey 791).

Embracing their blackness and cubanía, Los Paisanos conscientize Cubans with their lyrics, and serve as an inspiration to the revolution of the twenty-first century, the one that achieves and sustains appreciation of blackness and the collective integrity of African descendants. Likewise, Obsesión confronts the obsession with European hair and offers a re-conceptualization of Afro-Hispanic beauty. They call into question over four hundred years of indoctrination that disparages black heritage in Cuba-as in much of the African Diaspora-and compel their audience to debunk it.

This analysis of Cuban underground hip hop revives the discourse on the re-conceptualization of aesthetics as an essential part of the affirmation of Afro-Hispanic identity 
and the valorization of blackness as an integral part of the multi-cultural heritage of Cubans and of cubanía. In praising hair, Los Paisanos and Obsesión present songs of redemption and resistance and promotes blackness pari passu with their cubanidad, and they empower their compatriots and fellow African descendants to dismantle Eurocentric cultural domination and truly "advance the race," the human race.

\section{ENDNOTES}

1 Los Paisanos is a duo of underground hip hop rappers composed of Randy Acosta and Jessel "Mr Huevo" Saladriga ("Mr. Egg"). They formed in 1999 and performed under the direction of the Asociación Hermanos Saez. In 2003, they independently produced their first CD Paisanología. Obsesión is an underground hip hop husband and wife duo Magia López and Alexey Rodriguez. Originally, Obsesión was composed of about fifteen members in 1995. When the group disbanded, Rodríguez asked López to become part of the duo under the same name. They were foundational members of the Cuban Underground Hip Hip Movement (CUHHM) (Saunders 2015). López was the first female head of the Cuban Agency of Rap. Though the couple separated in 2010, they continue to work together (Perry 2016).
2 Cubaheadlines.com www.cubaheadlines.com/2013/ o1/01/36861/cuba\%E2\%80\%99s_parliament_and_the_ issue_of_race.html.

3 Los Paisanos are underground rappers who remain committed to the Cuban Underground Hip Hop Movement. In "Lo Negro," they question fellow rappers who switch to commercial rap, where social issues are not prominent themes, and lose focus on the power of conscious hip hop in liberating the mind. (Perry 2016).

4 The song was written by Soandry del Río and performed by the group Hermanos de Causa. (Saunders 2015). The lyrics of this song were published in the online journal Encuentro de la cultura cubana at http://www.cubaencuentro.com/ revista/revista-encuentro/archivo/53-54-verano-otono-2009/ poesia-rap-250584

\section{WORKS CITED}

Banks, Ingrid. Hair Matters: Beauty, Power, and Black Women's Consciousness. New York, NY: New York University Press, 2000.

"Cuba's Parliament and the Issue of Race." Cubaheadlines. com www.cubaheadlines.com/2013/01/01/36861/cuba\%E2\%80\%99s_parliament_and_the_issue_of_race. html, Accessed 1/1/2013.

De la Fuente, Alejandro. "The New Afro-Cuban Cultural Movement and the Debate on Race in Contemporary Cuba." Journal of Latin American Studies, Vol. 40, No. 4. Cambridge, England: Cambridge University Press, Nov. 2008, 697-720.

Del Río Ferrer, Soandry. “Poesía Rap.” Encuentro de la cultura cubana. Vol. 53/54, Madrid, Spain: Asociación Encuentro de la Cultura Cubana, summer/fall 2009.

Fanon, Frantz. Black Skin, White Masks. New York, NY: Grove Press, 1967.

Fernandes, Sujatha. "Fear of a Black Nation: Local Rappers, Transnational Crossings and State Power in Contemporary Cuba." Anthropological Quarterly. Vol. 74, No.4, Washington, DC: The George Washington University Institute for Ethnographic Research, 2003, 575-608.

---. Cuba Represent. Durham, NC: Duke University Press, 2006.
Garvey, Marcus. The Marcus Garvey and Universal Negro Improvement Association Papers, Vol. VII, Edi. Robert A. Hill. Berkeley, CA: University of California Press, 1990, 791. Hall, Marcella Runell. Education in a Hip Hop Nation: Our Identity, Politics and Pedagogy. Amherst, MA: University of Massachusetts, Dissertation, 2011.

Hermanos de Causa. "El negro cubano." Habana negra. YouTube uploaded by Ivan Barrios, December 1, 2014, www.//youtu. be/4wRJiKdydQc.

Jorge, Angela. "The Black Woman in Contemporary American Society." The Puerto Rican Woman: Perspectives on Culture, History and Society. Ed. Edna Acosta-Belén. New York, NY: Praeger, 1986, 180-187.

Kutzinski, Vera. Sugar's Secrets: Race and the Erotics of Cuban Nationalism. Charlottesville, VA: University Press of Virginia, 1993.

Lee, Spike. School Dayz. Brooklyn, NY: 40 Acres and a Mule Filmworks, 1988.

Marley, Bob. "Redemption Song." Thrift Gong. New York, NY: Island Records Ltd., 1984.

Martí, José. "Mi raza.” Sus Mejores Páginas. Edi. Raimundo Lazo. México: Editorial Porrua, 1972, 52-61.

Obsesión. “Los Pelos.” Grandes Cortoletrajes. 2011. Spotify, open. spotify.com/album/4koOpsJNiLowvC5HDePfUX. 
---. "Los Pelos." YouTube uploaded by hiphop4peacefestival, September 13, 2010, www.youtube.com/ watch?reload=9\&v=Epb_yN6KxWw.

Ortíz Fernández, Francisco. Cuban Counterpoint: Tobacco and Sugar. Trans. Harriet de Onís. Durham, N.C.: Duke UP, 1995.

---. "La cubanidad y los negros" Estudios afrocubanos. La Habana, Cuba: Sociedad de Estudios Afrocubanos, 1939, 3-15.

Oye Habana. "Negra.” La Emancipación 1. 2013. Spotify, open. spotify.com/artist/6TXuMxH9ByDVzF3fIXu3On?si=dFz6VmcGRxyPAFZIDWoX6A\#_=_.

---. "Negra." YouTube, uploaded by Yanet Cubanita, May 24, 2009, www.youtube.com/watch? $\mathrm{v}=\mathrm{c} 1 \mathrm{AX} 3 \mathrm{MAwk}$-g.

Paisanos, Los. "Lo negro." Paisanología. Independently produced. 2003.

---. "Lo negro.” YouTube uploaded by gohu94, December 26, 2009, www.youtube.com/watch?v=gI8A2xVKopU.

Perry, Marc D. Negro Soy Yo: Hip Hop and Raced Citizenship in Neoliberal Cuba. Durham, N.C.: Duke University Press, 2016.

Piedra, José. "Literary Whiteness and the Afro-Hispanic Difference." New Literary History, Vol. 18, No. 2. Baltimore, MD: The Johns Hopkins University Press, Winter 1987, pp. 303-332.
Rooks, Noliwe. Hair Raising: Beauty Culture and African American Women. New Brunswick, NJ: Rutgers University Press, 1996.

Saunders, Tanya L. Cuban Underground Hip Hop: Black Thoughts, Black Revolution, Black Modernity. Austin: University of Texas Press, 2015.

Steele, Claude M. "The Psychology of Self-affirmation: Sustaining the Integrity of the Self." In L. Berkowitz (Ed.), Advances in Experimental Social Psychology Vol. 21. San Diego, CA: Academic Press, 1988, 261-302.

Stolke (Martínez-Alier), Verena. Marriage, Class and Colour in Nineteenth-Century Cuba. Ann Arbor: The University of Michigan Press, 1989.

Watson, Sonja Stephenson. "Nationalist Rhetoric and Suppression of Black Consciousness: Literary Whiteness in Poems by Federico Escobar and Gaspar Octavio Hernández." Afro-Hispanic Review, Vol. 29, No. 1 Nashville, TN: SPRING 2010, pp. 169-186.

Whitten, Norman and Torres, Arlene. Blackness in Latin America and the Caribbean. Vol. 1. Bloomington, IN: Indiana University Press, 1998.

Zurbano, Roberto. "Racismo vs socialismo en Cuba: un conflicto fuera de lugar (apuntes sobre/contra el colonialismo interno)." MERIDIONAL Revista Chilena de Estudios Latinoamericanos, No. 4, Santiago de Chile: Universidad de Chile, April 2015, 11-40. 